Published in final edited form as:

Sci Transl Med. 2016 November 23; 8(366): 366ra161. doi:10.1126/scitranslmed.aah6904.

\title{
Lowered H3K27me3 and DNA hypomethylation define poorly prognostic pediatric posterior fossa ependymomas
}

\author{
Jill Bayliss ${ }^{*}, 1$, Piali Mukherjee ${ }^{*}, 2$, Chao Lu ${ }^{*}, 3$, Siddhant U. Jain ${ }^{4}$, Chan Chung ${ }^{1}$, Daniel \\ Martinez $^{5}$, Benjamin Sabari ${ }^{3}$, Ashley S. Margol ${ }^{6}$, Pooja Panwalkar ${ }^{1}$, Abhijit Parolia ${ }^{1,9}$, \\ Melike Pekmezci ${ }^{7}$, Richard C McEachin ${ }^{8}$, Marcin Cieslik ${ }^{9}$, Benita Tamrazi ${ }^{10}$, Benjamin A. \\ Garcia $^{11}$, Gaspare La Rocca ${ }^{12}$, Mariarita Santi ${ }^{5}$, Peter W. Lewis ${ }^{4}$, Cynthia Hawkins ${ }^{13}$, Ari \\ Melnick $^{2}$, C. David Allis ${ }^{3}$, Craig B. Thompson ${ }^{12}$, Arul M. Chinnaiyan ${ }^{1,9}$, Alexander R. \\ Judkins $^{14, \# \text {, and Sriram Venneti }}{ }^{1, \#}$ \\ ${ }^{1}$ Department of Pathology, University of Michigan, Ann Arbor, MI, 48104, USA \\ Epigenomics Core Facility, Weill Medical College of Cornell University, New York, NY, 10065, \\ USA
}

${ }^{3}$ Laboratory of Chromatin Biology \& Epigenetics, The Rockefeller University, New York, NY 10065, USA

${ }^{4}$ Department of Biomolecular Chemistry, School of Medicine and Public Health, University of Wisconsin, Madison, WI 53715, USA

${ }^{5}$ Department of Pathology, Children's Hospital of Philadelphia, University of Pennsylvania, PA, 19104, USA

${ }^{6}$ Department of Pediatrics, Children's Hospital Los Angeles, Keck School of Medicine University of Southern California, Los Angeles, CA, 90027, USA

${ }^{7}$ Department of Pathology, University of California, San Francisco, CA, 94143, USA

${ }^{8}$ Department of Computational Medicine \& Bioinformatics, University of Michigan, Ann Arbor, MI, 48104, USA

${ }^{9}$ Michigan Center for Translational Pathology, University of Michigan, Howard Hughes Medical Institute, University of Michigan, Ann Arbor, MI, 48104, USA

\footnotetext{
\#Correspondence to be addressed to: Alexander R. Judkins, MD, Department of Pathology and Laboratory Medicine, Children's Hospital Los Angeles, Keck School of Medicine of University of Southern California, 4650 Sunset Boulevard, MS \#43., Los Angeles, CA, 90027, Phone: 323-361-4516, ajudkins@ chla.usc.edu. Sriram Venneti, MD, PhD, Assistant Professor of Pathology, University of Michigan Medical School, University of Michigan, 3520E MSRB 1, 1150 W. Medical Center Dr., Ann Arbor, MI 41804, Phone: 734-763-0674, svenneti@med.umich.edu.

These authors contributed equally

Author contributions: JB, PM, CL, SUJ, CC, GL, DM, AP and SV performed experiments and analyzed data; ASM, MP and MS provided clinical data; CC and JB captured images in a blinded manner; RME, PM, BS, PP, and MC performed bioinformatics; BAG performed histone mass spectrometry; BT analyzed MRI scans in a blinded manner; SV, ARJ, MS, CH and MP are Neuropathologists who provided and assessed tumor samples; PWL, AM, DCA, CBT, AMC, ARJ and SV provided critical insights; JB, CL, ARJ and SV wrote and edited the paper; all authors provided edits and comments.

Competing interests: C.B.T is co-founder of Agios Pharmaceuticals and has financial interest in Agios. C.B.T is also on the Board of Directors of Merck and CRL. The authors of this study declare no other potential conflicts of interest.

Data and availability: The data for this study have been deposited in the database NCBI as GSE87779 and GSE89452.
} 
${ }^{10}$ Department of Radiology, Children's Hospital Los Angeles, Keck School of Medicine University of Southern California, Los Angeles, CA, 90027, USA

${ }^{11}$ Epigenetics Program, Department of Biochemistry and Biophysics, Perelman School of Medicine, University of Pennsylvania, Philadelphia, PA 19104, USA

${ }^{12}$ Cancer biology and genetics program, Memorial Sloan Kettering Cancer Center, New York, NY 10065, USA

${ }^{13}$ Arthur and Sonia Labatt Brain Tumour Research Centre and Division of Pathology, The Hospital for Sick Children, Toronto, Ontario, Canada. Department of Laboratory Medicine and

Pathobiology, Faculty of Medicine, University of Toronto, Toronto, Ontario, Canada

${ }^{14}$ Department of Pathology and Laboratory Medicine, Children's Hospital Los Angeles, Keck

School of Medicine University of Southern California, Los Angeles, CA, 90027, USA

\section{Abstract}

Childhood posterior fossa (PF) ependymomas cause substantial morbidity and mortality. These tumors lack recurrent genetic mutations but a subset of these ependymomas exhibit $\mathrm{CpG}$-island (CpGi) hypermethylation (PF group A; PFA), implicating epigenetic alterations in their pathogenesis. Further, histological grade does not reliably predict prognosis, highlighting the importance of developing more robust prognostic markers. We discovered global H3K27me3 reduction in a subset of these tumors (PF-ve ependymomas) analogous to H3K27M mutant gliomas. PF-ve tumors exhibited many clinical and biological similarities with PFA ependymomas. Genomic H3K27me3 distribution showed an inverse relationship with $\mathrm{CpGi}$ methylation, suggesting that $\mathrm{CpGi}$ hypermethylation drives low H3K27me3 in PF-ve ependymomas. Despite CpGi hypermethylation and global H3K27me3 reduction, these tumors showed DNA hypomethylation in the rest of the genome and exhibited increased H3K27me3 genomic enrichment at limited genomic loci similar to H3K27M mutant gliomas. Combined integrative analysis of PF-ve ependymomas with H3K27M gliomas uncovered common epigenetic deregulation of select factors that control radial glial biology, and PF radial glia in early human development exhibited reduced H3K27me3. Finally, H3K27me3 immunostaining served as a biomarker of poor prognosis and delineated radiologically invasive tumors, suggesting that reduced $\mathrm{H} 3 \mathrm{~K} 27 \mathrm{me} 3$ may be a prognostic indicator in PF ependymomas.

\section{Introduction}

Pediatric brain tumors are the most common solid malignancy of childhood and consist of diverse tumor types. Amongst these, pathogenesis of ependymomas, compared to that of medulloblastomas and pediatric glioblastomas (GBM), remains poorly understood. The World Health Organization (WHO) classifies ependymomas as grade II or grade III (anaplastic) based on histopathologic criteria (1). However, histopathologic grading correlates poorly with patient outcome and treatment response (2). Further, ependymomas show variable outcomes to therapy, with some patients responding well and others refractory to treatment $(3,4)$. Therefore there is an urgent and unmet need to better understand the biology of ependymomas to develop more robust disease biomarkers for prognosis and to create more effective treatments. 
Ependymomas develop throughout the neuraxis, but predominantly occur in three distinct regions: PF, supratentorial (ST, cerebral hemispheres), and spinal cord (SC) (1). PF ependymomas are frequently found in children, whereas ST and SC ependymomas are more common in adults $(1,2)$. Histologically, ependymomas within each of these locations have similar morphology but behave differently based on molecular heterogeneity. For example, $\mathrm{ST}$ ependymomas with poor prognosis have C11orf95-RELA fusions $(1,2,5)$. Similarly, PF ependymomas have been sub-grouped into PFA and group B (PFB) tumors based on gene expression profiles and CpGi methylation phenotype (CIMP) status (1, 2, 6-8). PFA ependymomas mainly occur in children, have a distinct gene expression profile, exhibit CpGi hypermethylation (CIMP+ve), are more invasive, and bear a worse prognosis. In contrast, PFB ependymomas occur in older individuals and younger adults, are CIMP-ve, less invasive, and carry a better prognosis $(1,2,6-8)$.

Two independent groups using whole exome and whole genome sequencing have demonstrated that PF ependymomas do not harbor recurrent genetic alterations (5, 7). CpGi hypermethylation in the absence of recurrent genetic changes in PFA ependymomas suggests that epigenetic mechanisms are central to PF ependymoma pathogenesis. Because DNA methylation and histone methylation are closely linked, we hypothesized that further elucidation of epigenomics in PF ependymomas, specifically evaluating histone modifications, would be key to understanding the biology of these tumors.

\section{Results}

\section{H3K27me3 is reduced in $\sim 80 \%$ of pediatric PF ependymomas}

To characterize epigenetic alterations, we first extracted histones from PF and ST ependymomas and performed mass spectrometry and Western blotting analyses. Mass spectrometry (Fig 1A, $p=0.016$ ) and Western blotting analysis showed that H3K27me3 was substantially reduced (Fig 1B-C, $p=0.002$ ) in PF ependymomas compared to ST, SC, and spinal myxopapillary ependymomas. A corresponding increase in $\mathrm{H} 3 \mathrm{~K} 27 \mathrm{ac}(p=0.005)$ in tumor samples with reduced H3K27me3 was also noted (Fig 1B-C). Other histone modifications including H3K9me3, H3K4me3, H3K36me2, H3K79me2, H3S28p, H4K20me3, H4K5ac, and H4K16ac were not significantly different between PF ependymomas and controls (Figs $1 \mathrm{~A}$ and S1A-E).

Because our Western blotting results suggested some degree of heterogeneity in H3K27me3 (reduction in 5/6 samples), we further characterized H3K27me3 by immunohistochemistry (IHC) in three (two pediatric and one adult) independent ependymoma tumor cohorts (Fig 1 D-L and Table 1). We observed a significant reduction ( $\mathrm{p}<0.0001)$ in $\mathrm{H} 3 \mathrm{~K} 27 \mathrm{me} 3$ (PF-ve) in tumor cells in $86 \%$ of PF samples in the first and $76 \%$ in the second pediatric cohorts (total $82 \%$ of pediatric PF ependymomas) (Table 1, Fig 1D-L). H3K27me3 was not reduced in the rest of the pediatric $\mathrm{PF}$ ependymomas (PF+ve, 18\% of total) or any other subtypes of pediatric and adult (third cohort) ependymomas (Fig $1 \mathrm{~F}-\mathrm{J}$ and Table 1). Reduction in H3K27me3 in PF-ve ependymomas was similar to that seen in histone H3K27M (K27M) mutant gliomas (Fig 1D-E, G, and J) (9, 10). Likewise, cells that retained H3K27me3 in PF -ve tumors were mainly endothelial cells and infiltrating immune cells (Figs 1 D-E, G, KL, and S1 F-G, arrows), serving as an internal control for IHC (Figs 1D and E, arrows). No 
significant differences in $\mathrm{H} 3 \mathrm{~K} 9 \mathrm{me} 3, \mathrm{H} 3 \mathrm{~K} 36 \mathrm{me} 3$, or $\mathrm{H} 3 \mathrm{~K} 36 \mathrm{me} 2$ immunostaining were observed in these samples (Fig S1C-E).

\section{PF-ve/PF+ve are clinical and biologically similar to PFA/PFB ependymomas}

We compared age, gender, and WHO grades between PF-ve and PF+ve ependymomas and included data from previously well-characterized PFA and PFB tumors in parallel (6). In pediatric tumors, both PF-ve (median 3.7 years) and PFA ependymomas (median 2.5 years) occurred in younger children in contrast to older age groups seen in $\mathrm{PF}+\mathrm{ve}$ (median 8.7 years) and PFB ependymomas (median 11 years) (Fig 2A). The gender distributions of PF $-\mathrm{ve} / \mathrm{PFA} / \mathrm{PF}+\mathrm{ve} / \mathrm{PFB}$ ependymomas were similar (Fig 2B). As previously reported (6), tumor grade did not show a clear distinction between $\mathrm{PF}-\mathrm{ve}$ and $\mathrm{PF}+\mathrm{ve}$ ependymomas (Figure S2A).

We next assessed gene expression and CpGi methylation in these tumors. Differences in gene expression between PF-ve vs. PF+ve [RNA-sequencing, (RNA-Seq)] significantly correlated $(\mathrm{r}=0.5671, \mathrm{p}<0.0001)$ with differences in gene expression between PFA vs. PFB tumors (6) (Fig 2C and S2B). PF-ve ependymomas showed significantly higher CpGi methylation ( $p=3.045 \mathrm{e}-07$ ) compared to PF+ve tumors (Fig 2D-E, S2C-F), as seen with PFA vs. PFB ependymomas (7). Moreover, the expression of genes that showed similar CpGi promoter differential methylation (7) in PF-ve vs. PF+ve and PFA vs. PFB ependymomas showed a significant correlation $(r=0.6157, \mathrm{p}<0.0001)$ (Fig S2D). Finally, H3K27me3 immunostaining was significantly lower $(\mathrm{p}<0.0001)$ in previously defined (8) PFA ependymomas compared to PFB tumors (Fig 2F). These data together suggest that PF $-\mathrm{ve} / \mathrm{PF}+\mathrm{ve}$ ependymomas share many clinical and biologic similarities with PFA/PFB ependymomas (Table S1).

\section{PF-ve ependymomas exhibit global DNA hypomethylation correlating to changes in gene expression}

Because our DNA methylation profiling was performed using enhanced reduced representation bisulfite sequencing (ERRBS), which provides a comprehensive genomic coverage, we extended our DNA methylation analysis beyond CpGi regions. PF-ve tumors showed significant genome-wide DNA hypomethylation in comparison to $\mathrm{PF}+\mathrm{ve}$ ( $p=1.56 \mathrm{e}-93$ ) (Figs 3A-E and S3A-G). To determine how DNA methylation impacted gene expression, differentially methylated regions (DMR) at genomic areas corresponding to gene promoters ( $5 \mathrm{~Kb}$ upstream of transcriptional start sites and $5^{\prime} \mathrm{UTR}$ ) were identified, including 213 genes that were differentially expressed in PF-ve tumors (Figs 3E-F). Promoter differential methylation showed a significant relationship with gene expression $(\mathrm{p}<0.0001$, Fig $\mathrm{S} 3 \mathrm{H})$. Hypomethylated DMRs in promoters were noted in $82 \%$ of upregulated genes (121/148, Fig 3F), including genes implicated in PF ependymomas such as AQP1 (11) and ALDH1L1 (6). Therefore, PF-ve ependymomas exhibit CpGi hypermethylation and global DNA hypomethylation correlating with increased gene expression compared to $\mathrm{PF}+\mathrm{ve}$ ependymomas. 


\section{H3K27me3 genomic distribution correlates with DNA methylation}

Reduced H3K27me3 in PF-ve ependymomas is not genetically driven, because targeted sequencing on 71 ependymoma samples (cohort 1) did not show recurrent mutations in factors regulating $\mathrm{H} 3 \mathrm{~K} 27 \mathrm{me} 3$, similar to results from two other independent groups $(5,7)$ (Table S2). Similarly, IHC, protein and gene expression for factors that regulate H3K27me3 could not explain reduced H3K27me3 in PF-ve tumors (Fig S4A-E), in agreement with EZH2 immunostaining data from others (12).

Recent studies have demonstrated that unmethylated CpGi recruit the PRC2 complex to increase H3K27me3 $(13,14)$. We therefore sought to assess the relationship between H3K27me3 and DNA methylation. First we assessed H3K27me3 genomic distribution using chromatin immunoprecipitation followed by sequencing (ChIP-seq) and compared this with gene expression (RNA-Seq). H3K27me3 marked many genetic loci in PF-ve ependymomas despite global reduction in H3K27me3 (Fig 4A-B). Consistently, gene expression showed an inverse relationship with the amount of $\mathrm{H} 3 \mathrm{~K} 27 \mathrm{me} 3$ and was significantly $(\mathrm{p}<0.0001)$ lower in genes that were enriched for $\mathrm{H} 3 \mathrm{~K} 27 \mathrm{me} 3$ at their promoters (Figs $4 \mathrm{~A}-\mathrm{C}$ and $\mathrm{S} 4 \mathrm{~F}-$ G). These genes included SIXI and BMP and activin membrane-bound inhibitor (BAMBI), which are implicated in neuroglial differentiation (Fig 4B-C and S4F). Moreover, low SIX1 and BAMBI expression was associated with worse prognosis in PF ependymomas (Fig 4D).

We then compared genomic H3K27me3 distribution with DNA methylation. H3K27me3 was significantly more enriched in hypomethylated $\mathrm{CpGi}(\mathrm{p}<0.0001)$ and showed an inverse relationship with CpGi methylation ( $\mathrm{r}=-0.4827$, $\mathrm{p}<0.0001)$ (Fig 4E-H and S4H). For example, DMRT2A, a gene that regulates neurogenesis (15), showed CpGi hypomethylation (mean meth diff $=-33.3$ ) and was enriched for H3K27me3 (7.4 fold increase) in PF-ve ependymomas (Fig 4F). In contrast, $L H X 2$, another neurogenesis regulator (16), showed low H3K27me3 (1.43 difference) but CpGi hypermethylation (mean meth diff $=48.4)$ (Fig 4G). Because PF-ve/PFA ependymomas exhibit higher CpGi methylation compared to PF $+\mathrm{ve} / \mathrm{PFB}$ ependymomas, the inverse relationship between H3K27me3 distribution and CpGi methylation suggests that aberrant DNA methylation may drive low H3K27me3 levels. Genes that showed differential DNA methylation or enrichment for H3K27me3 were involved in various neurodevelopmental functions when subjected to Database for Annotation, Visualization, and Integrated Discovery (DAVID, https://david.ncifcrf.gov/) analysis (Fig 4I and Table S3).

\section{PF-ve/PFA ependymomas share epigenetic similarities with H3K27M gliomas}

Similar to ependymomas, pediatric GBMs occur in PF (including diffuse pontine and cerebellar gliomas) and ST (or hemispheric) regions. PF gliomas carrying H3K27M mutations (60-80\%) are more common in children and, similar to PF-ve ependymomas, show global loss in H3K27me3. In contrast, H3K27me3 is retained in ST gliomas (which bear H3G34R/V (G34) mutations) and in ST ependymomas (with C11orf95-RELA fusions) $(5,17,18)$. Moreover, H3K27M gliomas, in addition to exhibiting reduced H3K27me3, are associated with genome-wide DNA hypomethylation (19). Because PF-ve/PFA ependymomas share many clinical (age, PF location) and molecular features with H3K27M gliomas, we compared genome-wide DNA methylation and H3K27me3 distribution in PF 
-ve/PFA ependymomas and H3K27M gliomas to gain further insights into the disease mechanism. Unsupervised cluster analyses of DNA methylation data derived from previously published datasets $(7,20)$ demonstrated that PFA ependymomas grouped mainly with H3K27M gliomas (Figs 5A and B). Genomic regions with similar methylation patterns $(\mathrm{n}=228)$ in both PFA and H3K27M, but not in G34R/V or PFB tumors included many promoter regions ( $\mathrm{n}=46 / 228$ ) (Fig S5A), including those of two genes important in radial glia biology, $P C D H 9$ (cadherin expressed in radial glia) and $S 100 B$ (glial calcium-binding protein, marker for radial glia). These two genes exhibited promoter DNA hypomethylation and increased expression in PFA and H3K27M but not PFB or G34 tumors (Fig 5C and S5B). Further, increased S100B and PCDH9 expression together correlated with poor prognosis in PF ependymomas (Fig 5D).

Despite genome-wide H3K27me3 decreases in H3K27M gliomas, certain genetic loci, including genes implicated in neuroglia lineage specification, display increased H3K27me3 $(19,21)$. We therefore compared our H3K27me3 ChIP-seq from PF-ve and ST ependymomas with two independently published H3K27me3 ChIP-seq datasets generated from H3.3 wild-type (WT) or H3K27M expressing neural progenitor cells (NPCs) (22) or H3K27M mutant and wild type glioma tumor samples (19). Unsupervised clustering of H3K27me3 ChIP-seq peaks showed that PF-ve tumors clustered with H3K27M NPCs but not ST ependymomas or WT NPCs ( $p=0.0075)$ (Fig 5E-F). Similarly, compared to ST ependymomas, $\mathrm{PF}-\mathrm{ve}$ tumors had significantly more H3K27me3 peaks $(\mathrm{p}=0.0041)$ that were also found in H3K27M gliomas but not $\mathrm{H} 3$ wild type gliomas (Fig S5E). We confirmed these results in previously published H3K27me3 ChIP-seq data from PFA and PFB ependymomas (7), where common peaks between PFA and H3K27M were significantly higher than those between PFB and H3K27M or WT NPCs ( $p<0.0001)$ (Fig 5G). H3K27me3 peaks ( $n=255$ ), which are common to PFA and H3K27M NPCs, corresponded largely to promoters $(248 / 255,97 \%$ ) (Fig S5C). Amongst them, genes that were downregulated in PFA and H3K27M have been implicated in radial glial development (EMX2) and neuronal patterning (HOXA7), which together correlated with poor prognosis (Figs 5F, $\mathrm{H}$ and I and S5D-E). To assess the functional relevance of genes that are epigenetically deregulated in both PF-ve and H3K27M tumors in an unbiased manner, we combined genes whose promoters exhibit differential DNA methylation ( $\mathrm{n}=46$, Fig. S5A-B) or H3K27me3 enrichment ( $\mathrm{n}=248$, Fig. S5C-D) and found that they showed $\sim 88 \%$ $(\mathrm{n}=258 / 294)$ overlap with published human radial glial signatures (23) (Fig 5J and Table S4). Functional analyses revealed that the top enriched categories were involved in neurodevelopment (fig. S5G and Table S5). Together, PFA/PF-ve ependymomas shared substantial similarities in DNA methylation and $\mathrm{H} 3 \mathrm{~K} 27 \mathrm{me} 3$ genomic distribution with H3K27M glioma, corresponding to genes involved in radial glial development and function.

\section{Radial glia in the developing cerebellum show reduced H3K27me3}

Our findings that factors involved in radial glial biology were epigenetically deregulated in $\mathrm{PF}-\mathrm{ve}$ ependymomas prompted us to assess $\mathrm{H} 3 \mathrm{~K} 27 \mathrm{me} 3$ in PF radial glia during development. Ependymomas are thought to arise from radial glia and express GFAP and S100B $(7,11,24,25)$. Radial glia have dual functions, serving as CNS progenitor stem cells as well as mediating neuronal migration (26). PF ependymomas mainly occur in the $4^{\text {th }}$ 
ventricular region (Fig S6A), where the cerebellum forms the roof and the brain stem forms the floor (Fig S6B). We therefore examined H3K27me3 in GFAP-positive radial glia in this region in non-pathologic human developing PF brain tissues (Figs 6, S6 and table S6).

In the developing PF, cerebellar radial glia mediate external granular layer neuronal precursor migration to their destination in the granular layer, completed by 2-3 months after birth (27). GFAP-positive cerebellar radial glia in the $4^{\text {th }}$ ventricle roof exhibited reduced H3K27me3 when the external granular layer was prominent prenatally but gained H3K27me3 when external granular layer migration was complete postnatally $(\mathrm{p}<0.0001)$ (Figs 6A-D, G-H, and S6C-F). In contrast, ependyma lining the $4^{\text {th }}$ ventricle floor showed comparatively higher H3K27me3 both before and after development (Fig 6E-H and S6GH). Human and mouse radial glia substantially differ in their gene expression patterns (28). Despite this, gene signatures that distinguish PFA from PFB ependymomas (6) showed similar trends in data derived from mouse developing (P6/P30) posterior fossa radial glia (Pearson's $r=0.4610, p=0.0354$ ), but showed the opposite trend in developing mouse external granular layer neurons (granular layer precursors/mature granular neurons, Pearson's r $=-0.5462$, p=0.0433) (29) (Fig 6I and S6I-J). Reduced H3K27me3 in PF-ve ependymomas and posterior fossa radial glia in early development is consistent with data that suggest radial glia as ependymoma candidate cells of origin $(11,25)$.

\section{H3K27me3 global reduction delineates poorly prognostic PF ependymomas}

We compared radiologic findings and overall survival in $\mathrm{PF}-\mathrm{ve}$ and $\mathrm{PF}+\mathrm{ve}$ ependymomas. $\mathrm{PF}-\mathrm{ve}$ tumors were radiologically and histologically more invasive than $\mathrm{PF}+\mathrm{ve}$ tumors $(p<0.0001)$ (Figs 7A-D). Further, PF-ve tumors were associated with overall higher rates of incomplete resection (subtotal and near total resection, Fig 7E), consistent with their invasive nature. $\mathrm{PF}-\mathrm{ve}$ tumors also exhibited significantly worse prognosis compared to $\mathrm{PF}$ + ve ependymomas in the pediatric cohort $(p=0.026$, Fig $7 \mathrm{~F})$ and in a larger sample size combining all three cohorts including adult ependymomas ( $p=0.0068$, Fig $7 \mathrm{G})$. We next determined if $\mathrm{H} 3 \mathrm{~K} 27 \mathrm{me} 3$ immunostaining could be a clinically important prognostic biomarker in PF ependymomas. Cox proportional hazards analysis confirmed H3K27me3 reduction, but not age, sex, or tumor grade as significant prognostic indicators ( $p=0.027$, Fig $7 \mathrm{H}$; extent of tumor resection was not included in this analysis because this information was available only in the first pediatric tumor cohort, Table 1; recurrence was not associated with poor prognosis possibly due to the relatively small sample size). In contrast, H3K9me3, H3K36me2, and H3K36me3 immunostaining did not show any relationship with overall survival (Fig S7A-C). Finally, the extent of H3K27me3 was reduced in matched primary and recurrent $\mathrm{PF}-\mathrm{ve}$ when compared to that observed in matched primary and recurrent ST ependymomas (Fig 7I). These data together suggest that reduced H3K27me3 by immunohistochemical staining is an independent prognostic indicator in pediatric $\mathrm{PF}$ ependymomas.

\section{Discussion}

We examined histone modifications to better understand the epigenome of childhood PF ependymomas. Our mass spectrometry, western blotting, and IHC analyses demonstrate that 
$\sim 80 \%$ PF ependymomas exhibit reduced $\mathrm{H} 3 \mathrm{~K} 27 \mathrm{me} 3$. Although the small sample size is a limitation of our study and our findings will need to be confirmed in a larger tumor cohort to assess the relationship between $\mathrm{H} 3 \mathrm{~K} 27 \mathrm{me} 3$ and PFA/PFB ependymomas, PF-ve ependymomas occurred in younger children, were more radiologically invasive, and defined poorly prognostic tumors sharing many similarities with previously described PFA ependymomas based on gene expression, CIMP status, and overall prognosis $(6,7)$. Our data, along with previous studies suggest that the molecular and epigenetic childhood PF ependymomas stratification may be prognostic (6-8).

The WHO Classification of Central Nervous System 2016 update includes molecular characteristics of ST ependymomas ( $R E L A$-fusion) underscoring the importance of integrating molecular and histopathologic criteria (1). In this context, H3K27me3 immunohistochemistry in PF ependymomas is easy to obtain and cost-effective across many clinical settings and surgical neuropathology practices, where methylation and gene expression arrays may not be readily available. Immunohistochemical staining for $\mathrm{H} 3 \mathrm{~K} 27 \mathrm{me} 3$ can therefore be used as a readily translatable prognostic molecular surrogate on routine formalin-fixed sections in pediatric PF ependymomas.

H3K27M mutations in PF gliomas dominantly inhibit EZH2 function, resulting in H3K27me3 global reduction (10). Two independent groups have shown that pediatric PF ependymomas do not bear recurrent genetic mutations, unlike H3K27M gliomas $(5,7)$. Consistent with these data, we found no recurrent mutations in factors that influence H3K27me3 in PF-ve ependymomas. Recent studies have documented a role for unmethylated $\mathrm{CpG}$ islands (CpGi) in PRC2 recruitment. Genome-wide analyses have revealed a strong positive correlation between methylation-free CpGi and PRC2 binding, and in vitro studies demonstrate that the recruitment and PRC2 activity depend on DNA methylation $(13,14,30)$. In our analyses, PF ependymomas showed an inverse relationship with CpGi methylation and H3K27me3 enrichment. Thus, the lowered H3K27me3 in these tumors may result from the inability of PRC2 to access chromatin due to increased $\mathrm{CpGi}$ methylation. However, the mechanisms that regulate aberrant DNA methylation in PF ependymomas are not known and require further elucidation. We also found that human PF radial glia displayed low H3K27me3 during early development. Therefore, reduced H3K27me3 in PF-ve ependymomas may also reflect the developmental window during which tumor formation occurs.

We found unexpected similarities in DNA methylation patterns and H3K27me3 genomewide distribution between PF-ve/PFA ependymomas and H3K27M gliomas, which correlated with a characteristic expression of genes critical for radial glial function and development. Because PF-ve/PFA ependymomas and H3K27M gliomas share many clinical features, including patient age and location, our observations suggest that a chromatin state defined by DNA and H3K27 hypomethylation may play a critical role in transformation and/or growth of tumor cells originating within the developing PF. Elucidating regulators of this shared chromatin state may be critical in understanding the biology of PF tumors and taking advantage of this potential therapeutic target. Our data suggest that H3K27me3 reduction may be of substantial importance in identifying ependymoma patients who would benefit from epigenetic therapies. 


\section{Materials and Methods}

\section{Study Design}

The objective of this study was to assess epigenetic modifications in childhood PF ependymomas. We observed a reduction in $\mathrm{H} 3 \mathrm{~K} 27 \mathrm{me} 3$ in PF ependymomas, which led us to hypothesize that reduced $\mathrm{H} 3 \mathrm{~K} 27 \mathrm{me} 3$ is central to PF ependymoma pathogenesis. Because ependymomas are rare tumors, no a priori power analysis was conducted to determine sample size. Sample size was determined based on frozen tissue availability and ranged from $\mathrm{n}=3-11$ (biological replicates) for methylation analyses, western blotting, and ChIPsequencing studies. No samples were excluded from data analyses. Tumor samples were obtained from Children's Hospital Los Angeles (CHLA), Children's Hospital Philadelphia (CHOP), University of California San Francisco (UCSF), and The Hospital for Sick Children, University of Toronto after institutional review board approval. All studies were conducted in compliance with REMARK guidelines for prognostic studies. All identifiers from cases were removed before analysis. Three independent neuropathologists reviewed H\&E sections in a non-blinded manner and assessed H3K27me3 immunostaining in a blinded manner. Image capturing and analyses was performed in a blinded manner.

Statistics-Statistical analyses were performed in consultation with the department of Computational Medicine \& Bioinformatics at the University of Michigan. Graphs were plotted and statistical analyses were performed using Prism software (version 6, Graphpad). Unpaired, two-tailed, two-sided Student's $t$ test, two-sided Chi square test, two-sided analysis of variance (ANOVA) followed by post hoc Bonferroni multiple comparison analysis, and two-sample Mann-Whitney U/Wilcoxon test were used to analyze data as indicated. Z-scores were used to segregate high and low expression cutoffs for each marker based on methodology from the cancer genome atlas (TCGA). Overall survival data were plotted as Kaplan-Meier curves and analyzed using log-rank (Mantel-Cox) test. Multivariate survival analysis was performed using Cox proportional hazards model in SSPS (version 22, IBM). The hazard ratio represented by the SSPS software as $\operatorname{Exp}(B)$ is defined as a ratio of death probabilities in $\mathrm{PF}-\mathrm{ve}$ versus $\mathrm{PF}+\mathrm{ve}$ ependymomas. Data were considered significant if $p$ values were below 0.05 (95\% confidence intervals); $n$ and $p$ values are reported in figure legends and table $\mathrm{S} 7$.

\section{Supplementary Material}

Refer to Web version on PubMed Central for supplementary material.

\section{Acknowledgments}

We thank Dmitry Yarilin, Jianan Zhang, Agnes Viale and Nicholas Socci (MSKCC); Christopher Edwards, Christopher Paran: (Univ of Michigan); Alicia Alonso (Weil Cornell) and Karen Miller (CHLA) for experimental and data analysis help. We thank Adriana Heguy, Igor Dolgalev (NYU) and the New York Genome Center for help with sequencing studies. We thank Tullia Lindsten and Dennis Pozega and for critical reading of the manuscript.

Funding: This work was supported by grants from NCI K08 CA181475 (S.V.), Mathew Larson Foundation (SV), Sidney Kimmel Foundation (SV), Doris Duke Foundation (SV), RO1GM110174 and P01CA196539 (BAG). RCM is supported by the University of Michigan Bioinformatics Core. C.L. is the Kandarian Family Fellow supported by the Damon Runyon Cancer Research Foundation (DRG-2195-14). CBT is supported by the Cancer Center Support Grant (CCSG) of Memorial Sloan Kettering Cancer Center (CBT)--NIH P30 CA008748. 


\section{References and notes}

1. Louis DN, Perry A, Reifenberger G, von Deimling A, Figarella-Branger D, Cavenee WK, Ohgaki H, Wiestler OD, Kleihues P, Ellison DW. The 2016 World Health Organization Classification of Tumors of the Central Nervous System: a summary. Acta Neuropathol. 2016; 131:803-820. [PubMed: 27157931]

2. Pajtler KW, Witt H, Sill M, Jones DT, Hovestadt V, Kratochwil F, Wani K, Tatevossian R, Punchihewa C, Johann P, Reimand J, Warnatz HJ, Ryzhova M, Mack S, Ramaswamy V, Capper D, Schweizer L, Sieber L, Wittmann A, Huang Z, van Sluis P, Volckmann R, Koster J, Versteeg R, Fults D, Toledano H, Avigad S, Hoffman LM, Donson AM, Foreman N, Hewer E, Zitterbart K, Gilbert M, Armstrong TS, Gupta N, Allen JC, Karajannis MA, Zagzag D, Hasselblatt M, Kulozik AE, Witt O, Collins VP, von Hoff K, Rutkowski S, Pietsch T, Bader G, Yaspo ML, von Deimling A, Lichter P, Taylor MD, Gilbertson R, Ellison DW, Aldape K, Korshunov A, Kool M, Pfister SM. Molecular Classification of Ependymal Tumors across All CNS Compartments, Histopathological Grades, and Age Groups. Cancer cell. 2015; 27:728-743. [PubMed: 25965575]

3. Grundy RG, Wilne SA, Weston CL, Robinson K, Lashford LS, Ironside J, Cox T, Chong WK, Campbell RH, Bailey CC, Gattamaneni R, Picton S, Thorpe N, Mallucci C, English MW, Punt JA, Walker DA, Ellison DW, Machin D. C Children's. C. Leukaemia Group Brain Tumour. Primary postoperative chemotherapy without radiotherapy for intracranial ependymoma in children: the UKCCSG/SIOP prospective study. Lancet Oncol. 2007; 8:696-705. [PubMed: 17644039]

4. Merchant TE, Mulhern RK, Krasin MJ, Kun LE, Williams T, Li C, Xiong X, Khan RB, Lustig RH, Boop FA, Sanford RA. Preliminary results from a phase II trial of conformal radiation therapy and evaluation of radiation-related CNS effects for pediatric patients with localized ependymoma. Journal of clinical oncology : official journal of the American Society of Clinical Oncology. 2004; 22:3156-3162. [PubMed: 15284268]

5. Parker M, Mohankumar KM, Punchihewa C, Weinlich R, Dalton JD, Li Y, Lee R, Tatevossian RG, Phoenix TN, Thiruvenkatam R, White E, Tang B, Orisme W, Gupta K, Rusch M, Chen X, Li Y, Nagahawhatte P, Hedlund E, Finkelstein D, Wu G, Shurtleff S, Easton J, Boggs K, Yergeau D, Vadodaria B, Mulder HL, Becksfort J, Gupta P, Huether R, Ma J, Song G, Gajjar A, Merchant T, Boop F, Smith AA, Ding L, Lu C, Ochoa K, Zhao D, Fulton RS, Fulton LL, Mardis ER, Wilson RK, Downing JR, Green DR, Zhang J, Ellison DW, Gilbertson RJ. C11orf95-RELA fusions drive oncogenic NF-kappaB signalling in ependymoma. Nature. 2014; 506:451-455. [PubMed: 24553141]

6. Witt H, Mack SC, Ryzhova M, Bender S, Sill M, Isserlin R, Benner A, Hielscher T, Milde T, Remke M, Jones DT, Northcott PA, Garzia L, Bertrand KC, Wittmann A, Yao Y, Roberts SS, Massimi L, Van Meter T, Weiss WA, Gupta N, Grajkowska W, Lach B, Cho YJ, von Deimling A, Kulozik AE, Witt O, Bader GD, Hawkins CE, Tabori U, Guha A, Rutka JT, Lichter P, Korshunov A, Taylor MD, Pfister SM. Delineation of two clinically and molecularly distinct subgroups of posterior fossa ependymoma. Cancer cell. 2011; 20:143-157. [PubMed: 21840481]

7. Mack SC, Witt H, Piro RM, Gu L, Zuyderduyn S, Stutz AM, Wang X, Gallo M, Garzia L, Zayne K, Zhang X, Ramaswamy V, Jager N, Jones DT, Sill M, Pugh TJ, Ryzhova M, Wani KM, Shih DJ, Head R, Remke M, Bailey SD, Zichner T, Faria CC, Barszczyk M, Stark S, Seker-Cin H, Hutter S, Johann P, Bender S, Hovestadt V, Tzaridis T, Dubuc AM, Northcott PA, Peacock J, Bertrand KC, Agnihotri S, Cavalli FM, Clarke I, Nethery-Brokx K, Creasy CL, Verma SK, Koster J, Wu X, Yao Y, Milde T, Sin-Chan P, Zuccaro J, Lau L, Pereira S, Castelo-Branco P, Hirst M, Marra MA, Roberts SS, Fults D, Massimi L, Cho YJ, Van Meter T, Grajkowska W, Lach B, Kulozik AE, von Deimling A, Witt O, Scherer SW, Fan X, Muraszko KM, Kool M, Pomeroy SL, Gupta N, Phillips J, Huang A, Tabori U, Hawkins C, Malkin D, Kongkham PN, Weiss WA, Jabado N, Rutka JT, Bouffet E, Korbel JO, Lupien M, Aldape KD, Bader GD, Eils R, Lichter P, Dirks PB, Pfister SM, Korshunov A, Taylor MD. Epigenomic alterations define lethal CIMP-positive ependymomas of infancy. Nature. 2014; 506:445-450. [PubMed: 24553142]

8. Ramaswamy V, Hielscher T, Mack SC, Lassaletta A, Lin T, Pajtler KW, Jones DT, Luu B, Cavalli FM, Aldape K, Remke M, Mynarek M, Rutkowski S, Gururangan S, McLendon RE, Lipp ES, Dunham C, Hukin J, Eisenstat DD, Fulton D, van Landeghem FK, Santi M, van Veelen ML, Van Meir EG, Osuka S, Fan X, Muraszko KM, Tirapelli DP, Oba-Shinjo SM, Marie SK, Carlotti CG, Lee JY, Rao AA, Giannini C, Faria CC, Nunes S, Mora J, Hamilton RL, Hauser P, Jabado N, 
Petrecca K, Jung S, Massimi L, Zollo M, Cinalli G, Bognar L, Klekner A, Hortobagyi T, Leary S, Ermoian RP, Olson JM, Leonard JR, Gardner C, Grajkowska WA, Chambless LB, Cain J, Eberhart CG, Ahsan S, Massimino M, Giangaspero F, Buttarelli FR, Packer RJ, Emery L, Yong WH, Soto H, Liau LM, Everson R, Grossbach A, Shalaby T, Grotzer M, Karajannis MA, Zagzag D, Wheeler H, von Hoff K, Alonso MM, Tunon T, Schuller U, Zitterbart K, Sterba J, Chan JA, Guzman M, Elbabaa SK, Colman H, Dhall G, Fisher PG, Fouladi M, Gajjar A, Goldman S, Hwang E, Kool M, Ladha H, Vera-Bolanos E, Wani K, Lieberman F, Mikkelsen T, Omuro AM, Pollack IF, Prados M, Robins HI, Soffietti R, Wu J, Metellus P, Tabori U, Bartels U, Bouffet E, Hawkins CE, Rutka JT, Dirks P, Pfister SM, Merchant TE, Gilbert MR, Armstrong TS, Korshunov A, Ellison DW, Taylor MD. Therapeutic Impact of Cytoreductive Surgery and Irradiation of Posterior Fossa Ependymoma in the Molecular Era: A Retrospective Multicohort Analysis. Journal of clinical oncology : official journal of the American Society of Clinical Oncology. 2016; 34:2468-2477. [PubMed: 27269943]

9. Venneti S, Garimella MT, Sullivan LM, Martinez D, Huse JT, Heguy A, Santi M, Thompson CB, Judkins AR. Evaluation of histone 3 lysine 27 trimethylation (H3K27me3) and enhancer of Zest 2 (EZH2) in pediatric glial and glioneuronal tumors shows decreased H3K27me3 in H3F3A K27M mutant glioblastomas. Brain Pathol. 2013; 23:558-564. [PubMed: 23414300]

10. Lewis PW, Muller MM, Koletsky MS, Cordero F, Lin S, Banaszynski LA, Garcia BA, Muir TW, Becher OJ, Allis CD. Inhibition of PRC2 Activity by a Gain-of-Function H3 Mutation Found in Pediatric Glioblastoma. Science. 2013; 340:857-861. [PubMed: 23539183]

11. Taylor MD, Poppleton H, Fuller C, Su X, Liu Y, Jensen P, Magdaleno S, Dalton J, Calabrese C, Board J, Macdonald T, Rutka J, Guha A, Gajjar A, Curran T, Gilbertson RJ. Radial glia cells are candidate stem cells of ependymoma. Cancer cell. 2005; 8:323-335. [PubMed: 16226707]

12. Li AM, Dunham C, Tabori U, Carret AS, McNeely PD, Johnston D, Lafay-Cousin L, Wilson B, Eisenstat DD, Jabado N, Zelcer S, Silva M, Scheinemann K, Fryer C, Hendson G, Fotovati A, Hawkins C, Yip S, Dunn SE, Hukin J. EZH2 expression is a prognostic factor in childhood intracranial ependymoma: a Canadian Pediatric Brain Tumor Consortium study. Cancer. 2015; 121:1499-1507. [PubMed: 25586788]

13. Mendenhall EM, Koche RP, Truong T, Zhou VW, Issac B, Chi AS, Ku M, Bernstein BE. GC-rich sequence elements recruit PRC2 in mammalian ES cells. PLoS genetics. 2010; 6:e1001244. [PubMed: 21170310]

14. Reddington JP, Perricone SM, Nestor CE, Reichmann J, Youngson NA, Suzuki M, Reinhardt D, Dunican DS, Prendergast JG, Mjoseng H, Ramsahoye BH, Whitelaw E, Greally JM, Adams IR, Bickmore WA, Meehan RR. Redistribution of H3K27me3 upon DNA hypomethylation results in de-repression of Polycomb target genes. Genome biology. 2013; 14:R25. [PubMed: 23531360]

15. Yoshizawa A, Nakahara Y, Izawa T, Ishitani T, Tsutsumi M, Kuroiwa A, Itoh M, Kikuchi Y. Zebrafish Dmrta2 regulates neurogenesis in the telencephalon. Genes to cells : devoted to molecular \& cellular mechanisms. 2011; 16:1097-1109. [PubMed: 22023386]

16. Hsu LC, Nam S, Cui Y, Chang CP, Wang CF, Kuo HC, Touboul JD, Chou SJ. Lhx2 regulates the timing of beta-catenin-dependent cortical neurogenesis. Proceedings of the National Academy of Sciences of the United States of America. 2015; 112:12199-12204. [PubMed: 26371318]

17. Schwartzentruber J, Korshunov A, Liu XY, Jones DT, Pfaff E, Jacob K, Sturm D, Fontebasso AM, Quang DA, Tonjes M, Hovestadt V, Albrecht S, Kool M, Nantel A, Konermann C, Lindroth A, Jager N, Rausch T, Ryzhova M, Korbel JO, Hielscher T, Hauser P, Garami M, Klekner A, Bognar L, Ebinger M, Schuhmann MU, Scheurlen W, Pekrun A, Fruhwald MC, Roggendorf W, Kramm C, Durken M, Atkinson J, Lepage P, Montpetit A, Zakrzewska M, Zakrzewski K, Liberski PP, Dong Z, Siegel P, Kulozik AE, Zapatka M, Guha A, Malkin D, Felsberg J, Reifenberger G, von Deimling A, Ichimura K, Collins VP, Witt H, Milde T, Witt O, Zhang C, Castelo-Branco P, Lichter P, Faury D, Tabori U, Plass C, Majewski J, Pfister SM, Jabado N. Driver mutations in histone H3.3 and chromatin remodelling genes in paediatric glioblastoma. Nature. 2012; 482:226-231. [PubMed: 22286061]

18. Wu G, Broniscer A, McEachron TA, Lu C, Paugh BS, Becksfort J, Qu C, Ding L, Huether R, Parker M, Zhang J, Gajjar A, Dyer MA, Mullighan CG, Gilbertson RJ, Mardis ER, Wilson RK, Downing JR, Ellison DW, Baker SJ. Somatic histone H3 alterations in pediatric diffuse intrinsic pontine gliomas and non-brainstem glioblastomas. Nature genetics. 2012; 44:251-253. [PubMed: 22286216] 
19. Bender S, Tang Y, Lindroth AM, Hovestadt V, Jones DT, Kool M, Zapatka M, Northcott PA, Sturm D, Wang W, Radlwimmer B, Hojfeldt JW, Truffaux N, Castel D, Schubert S, Ryzhova M, SekerCin H, Gronych J, Johann PD, Stark S, Meyer J, Milde T, Schuhmann M, Ebinger M, Monoranu CM, Ponnuswami A, Chen S, Jones C, Witt O, Collins VP, von Deimling A, Jabado N, Puget S, Grill J, Helin K, Korshunov A, Lichter P, Monje M, Plass C, Cho YJ, Pfister SM. Reduced H3K27me3 and DNA hypomethylation are major drivers of gene expression in K27M mutant pediatric high-grade gliomas. Cancer cell. 2013; 24:660-672. [PubMed: 24183680]

20. Sturm D, Witt H, Hovestadt V, Khuong-Quang DA, Jones DT, Konermann C, Pfaff E, Tonjes M, Sill M, Bender S, Kool M, Zapatka M, Becker N, Zucknick M, Hielscher T, Liu XY, Fontebasso AM, Ryzhova M, Albrecht S, Jacob K, Wolter M, Ebinger M, Schuhmann MU, van Meter T, Fruhwald MC, Hauch H, Pekrun A, Radlwimmer B, Niehues T, von Komorowski G, Durken M, Kulozik AE, Madden J, Donson A, Foreman NK, Drissi R, Fouladi M, Scheurlen W, von Deimling A, Monoranu C, Roggendorf W, Herold-Mende C, Unterberg A, Kramm CM, Felsberg J, Hartmann C, Wiestler B, Wick W, Milde T, Witt O, Lindroth AM, Schwartzentruber J, Faury D, Fleming A, Zakrzewska M, Liberski PP, Zakrzewski K, Hauser P, Garami M, Klekner A, Bognar L, Morrissy S, Cavalli F, Taylor MD, van Sluis P, Koster J, Versteeg R, Volckmann R, Mikkelsen T, Aldape K, Reifenberger G, Collins VP, Majewski J, Korshunov A, Lichter P, Plass C, Jabado N, Pfister SM. Hotspot Mutations in H3F3A and IDH1 Define Distinct Epigenetic and Biological Subgroups of Glioblastoma. Cancer cell. 2012; 22:425-437. [PubMed: 23079654]

21. Chan KM, Fang D, Gan H, Hashizume R, Yu C, Schroeder M, Gupta N, Mueller S, James CD, Jenkins R, Sarkaria J, Zhang Z. The histone H3.3K27M mutation in pediatric glioma reprograms H3K27 methylation and gene expression. Genes \& development. 2013; 27:985-990. [PubMed: 23603901]

22. Funato K, Major T, Lewis PW, Allis CD, Tabar V. Use of human embryonic stem cells to model pediatric gliomas with H3.3K27M histone mutation. Science. 2014; 346:1529-1533. [PubMed: 25525250]

23. Lui JH, Nowakowski TJ, Pollen AA, Javaherian A, Kriegstein AR, Oldham MC. Radial glia require PDGFD-PDGFRbeta signalling in human but not mouse neocortex. Nature. 2014; 515:264-268. [PubMed: 25391964]

24. Louis DN, Ohgaki H, Wiestler OD, Cavenee WK, Burger PC, Jouvet A, Scheithauer BW, Kleihues P. The 2007 WHO classification of tumours of the central nervous system (vol 114, pg 97, 2007). Acta neuropathologica. 2007; 114:547-547.

25. Johnson RA, Wright KD, Poppleton H, Mohankumar KM, Finkelstein D, Pounds SB, Rand V, Leary SE, White E, Eden C, Hogg T, Northcott P, Mack S, Neale G, Wang YD, Coyle B, Atkinson J, DeWire M, Kranenburg TA, Gillespie Y, Allen JC, Merchant T, Boop FA, Sanford RA, Gajjar A, Ellison DW, Taylor MD, Grundy RG, Gilbertson RJ. Cross-species genomics matches driver mutations and cell compartments to model ependymoma. Nature. 2010; 466:632-636. [PubMed: 20639864]

26. De Juan Romero C, Borrell V. Coevolution of radial glial cells and the cerebral cortex. Glia. 2015; 63:1303-1319. [PubMed: 25808466]

27. Frank CL, Liu F, Wijayatunge R, Song L, Biegler MT, Yang MG, Vockley CM, Safi A, Gersbach CA, Crawford GE, West AE. Regulation of chromatin accessibility and Zic binding at enhancers in the developing cerebellum. Nat Neurosci. 2015; 18:647-656. [PubMed: 25849986]

28. Pollen AA, Nowakowski TJ, Chen J, Retallack H, Sandoval-Espinosa C, Nicholas CR, Shuga J, Liu SJ, Oldham MC, Diaz A, Lim DA, Leyrat AA, West JA, Kriegstein AR. Molecular Identity of Human Outer Radial Glia during Cortical Development. Cell. 2015; 163:55-67. [PubMed: 26406371]

29. Koirala S, Corfas G. Identification of novel glial genes by single-cell transcriptional profiling of Bergmann glial cells from mouse cerebellum. PLoS One. 2010; 5:e9198. [PubMed: 20169146]

30. Mohn F, Weber M, Rebhan M, Roloff TC, Richter J, Stadler MB, Bibel M, Schubeler D. Lineagespecific polycomb targets and de novo DNA methylation define restriction and potential of neuronal progenitors. Molecular cell. 2008; 30:755-766. [PubMed: 18514006] 


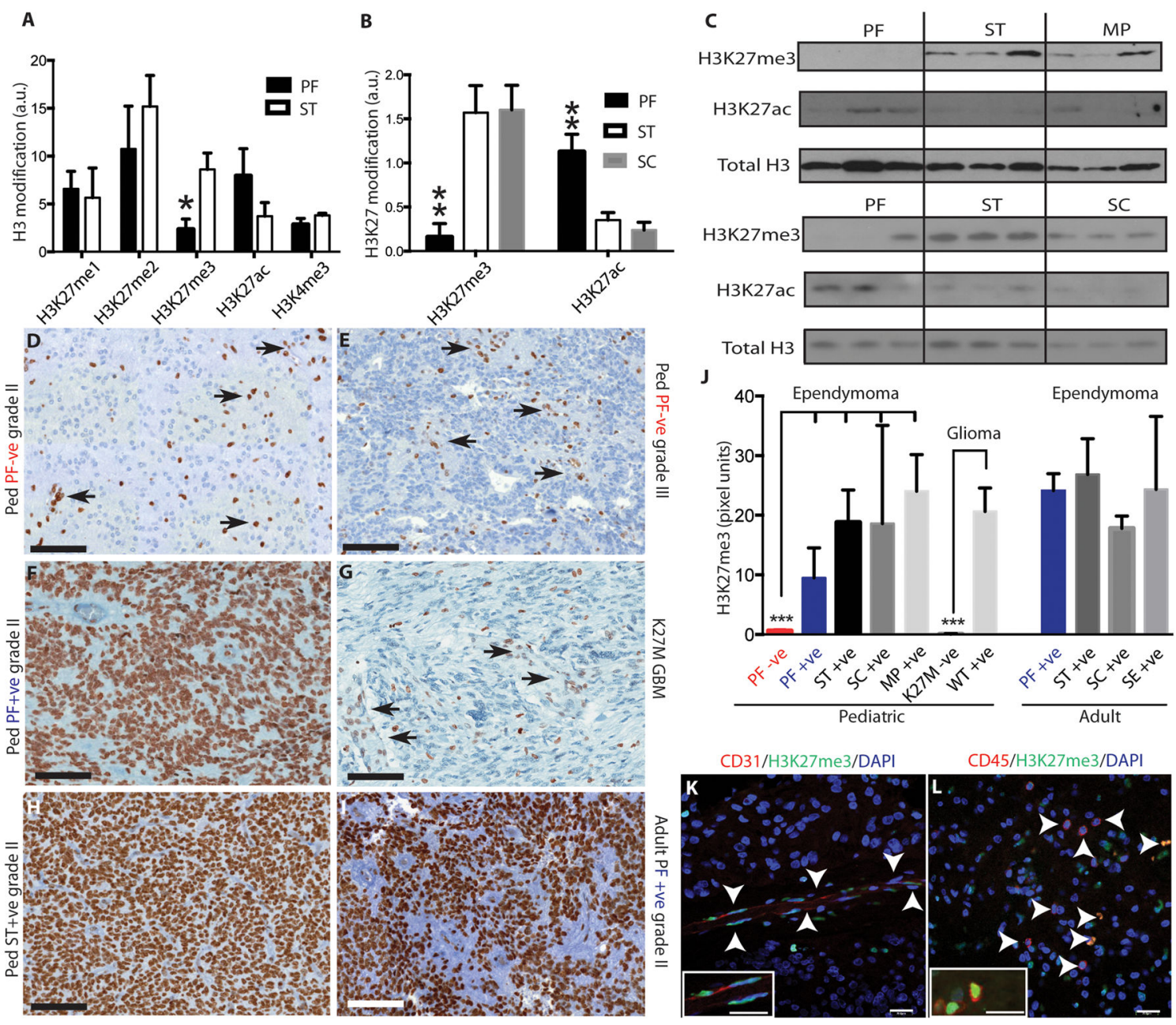

Figure 1. H3K27me3 is globally reduced in a subset of pediatric PF ependymomas

A. Mass spectrometry of H3K27 and H3K4 modifications in pediatric PF $(n=5)$ and ST ( $\mathrm{n}=3$, except for H3K27ac $\mathrm{n}=2$ ) ependymomas. * $p=0.016$

B. Quantification of H3K27me3 and H3K27ac Western blots normalized to total histone H3 content in PF ( $\mathrm{n}=6)$, ST $(\mathrm{n}=6)$, and SC $(\mathrm{n}=3)$ ependymomas. ** $p=0.002$ for H3K27me3 and $* * p=0.005$ for $\mathrm{H} 3 \mathrm{~K} 27 \mathrm{ac}$.

C. Western blots for H3K27me3, H3K27ac, and total histone H3 quantified in B.

D-I. Representative H3K27me3 IHC staining in pediatric PF (D-F) ependymomas; H3K27M mutant GBM $(\mathrm{G})$; pediatric ST (H) and adult PF (I) ependymomas. Arrows indicate $\mathrm{H} 3 \mathrm{~K} 27 \mathrm{me} 3$ positive endothelial and immune cells as internal control. Scale bars represent $200 \mu \mathrm{M}$.

J. Quantification of H3K27me3 IHC in pediatric and adult ependymomas, and H3K27M and WT GBM (for $\mathrm{n}$ see table $\mathrm{S} 7$ ); *** $p<0.0001$.

$\mathrm{K}-\mathrm{L}$. Representative composite immunofluorescence images for endothelial marker (K, CD31, red) or leukocyte common antigen (L, CD45, red); H3K27me3 (green); and DAPI (blue) in a PF-ve ependymoma. Arrowheads indicate H3K27me3 positive non-tumor cells. Scale bars represent $20 \mu \mathrm{M}$. 
Data are represented as mean \pm SEM. Statistical significance in A, B and $\mathbf{J}$ was determined by two-sided, unpaired, two-tailed, Student's $t$ test. SC = spinal cord ependymoma, MP = myxopapillary spinal ependymoma, $\mathrm{SE}=$ subependymoma, and $\mathrm{WT}=\mathrm{H} 3$ wild type glioma. 
A
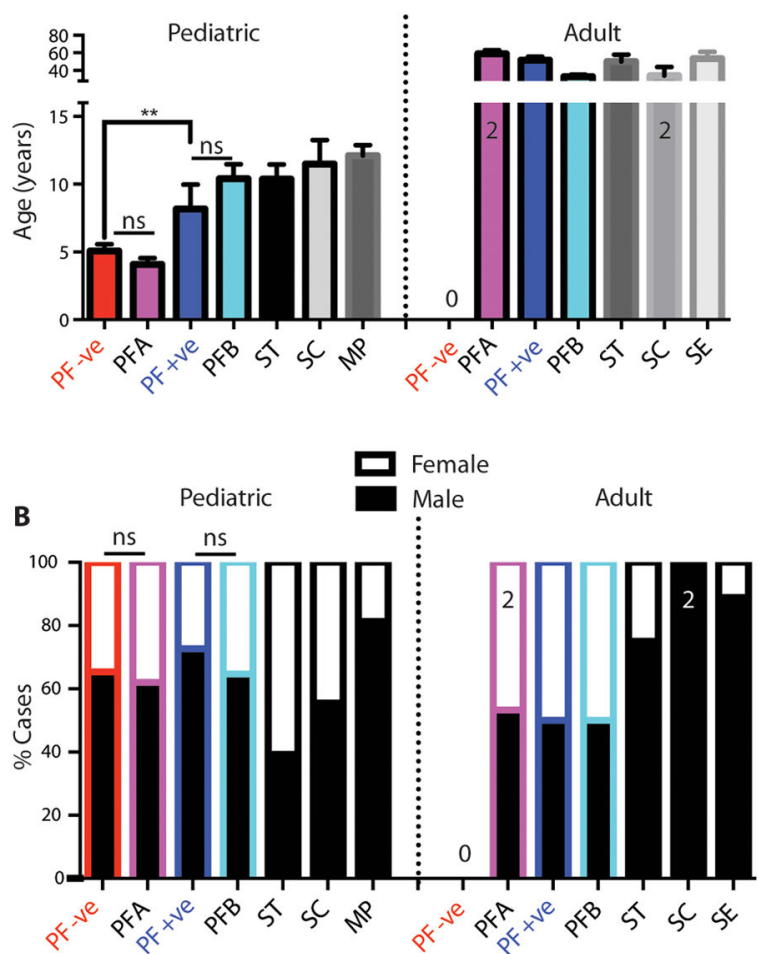

C

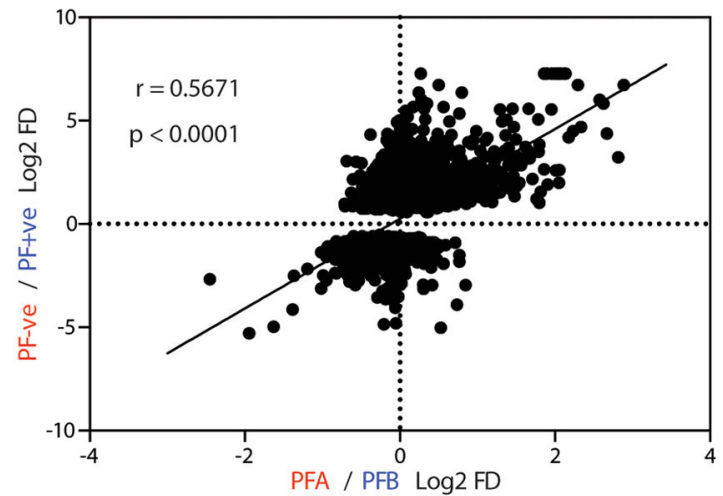

D
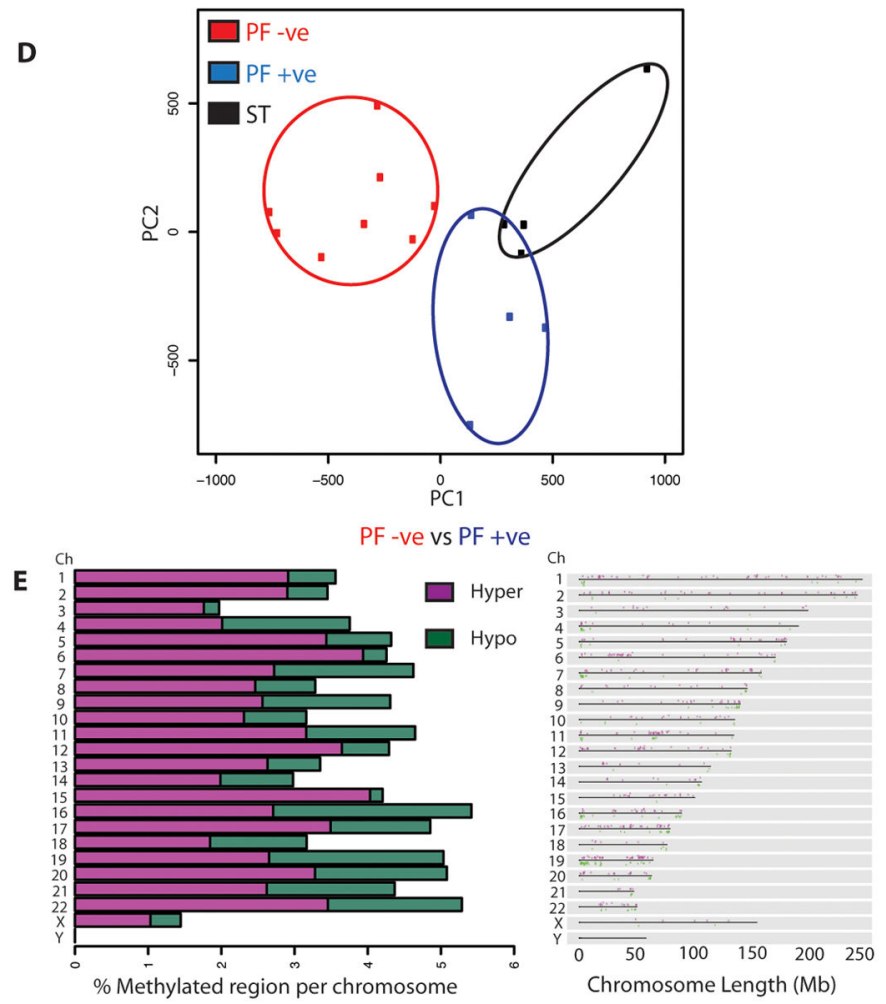

$\mathbf{F}$
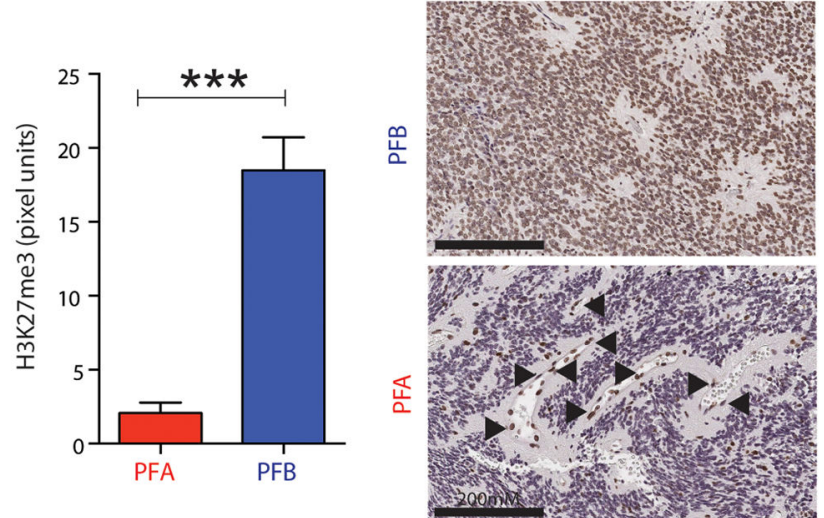

Figure 2. PF-ve tumors share clinical and biological features with PFA ependymomas A-B. Age (A) and gender (B) distribution in ependymomas (6) immunostained with $\mathrm{H} 3 \mathrm{~K} 27 \mathrm{me} 3$. ${ }^{*} p=0.026$. (for $\mathrm{n}$ see table $\mathrm{S} 7$; number of cases is indicated when $\mathrm{n}<3$ ). C. Comparison of gene expression between PF-ve/PF+ve $(n=11 / 4, Y$-axis $)$ and PFA/PFB ((6) $n=18 / 19, X$-axis) ependymomas.

D. Principal component (PC) analysis of CpGi methylation in $P F-v e(n=8), P F+v e(n=4)$, and ST $(n=4)$ ependymomas.

E. CpGi methylation per chromosome (bar plot and ideogram) indicating hypermethylated (pink) and hypomethylated (green) regions from $\mathrm{PF}-\mathrm{ve}(\mathrm{n}=8)$ and $\mathrm{PF}+\mathrm{ve}(\mathrm{n}=4)$ ependymomas. 
F. H3K27me3 immunohistochemistry from previously defined PFA $(n=13)$ and PFB $(n=3)$ pediatric ependymomas $* * * p<0.0001$. Arrows indicate $\mathrm{H} 3 \mathrm{~K} 27 \mathrm{me} 3$ positive endothelial and immune cells used as internal control. Scale bars represent $60 \mu \mathrm{M}$.

Data are represented as means \pm SEM. Statistical significance was determined in A and $\mathrm{F}$ by two-sided, unpaired, two-tailed Student's $t$ test; in B by two-tailed Chi square test, and in C by two-tailed Pearson's Correlation. 

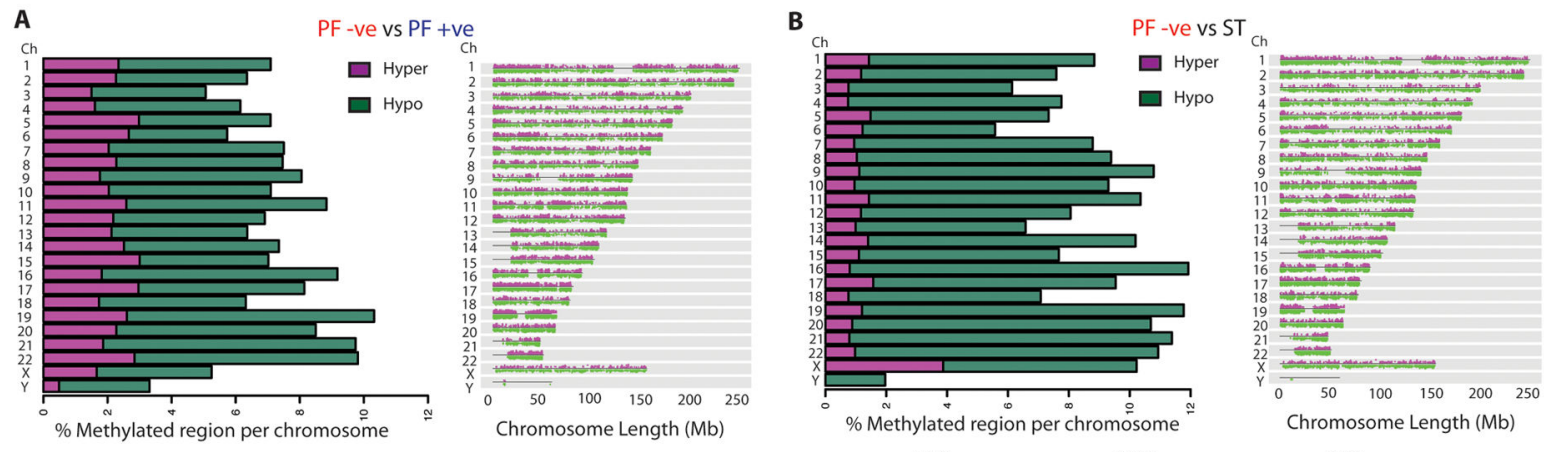

C
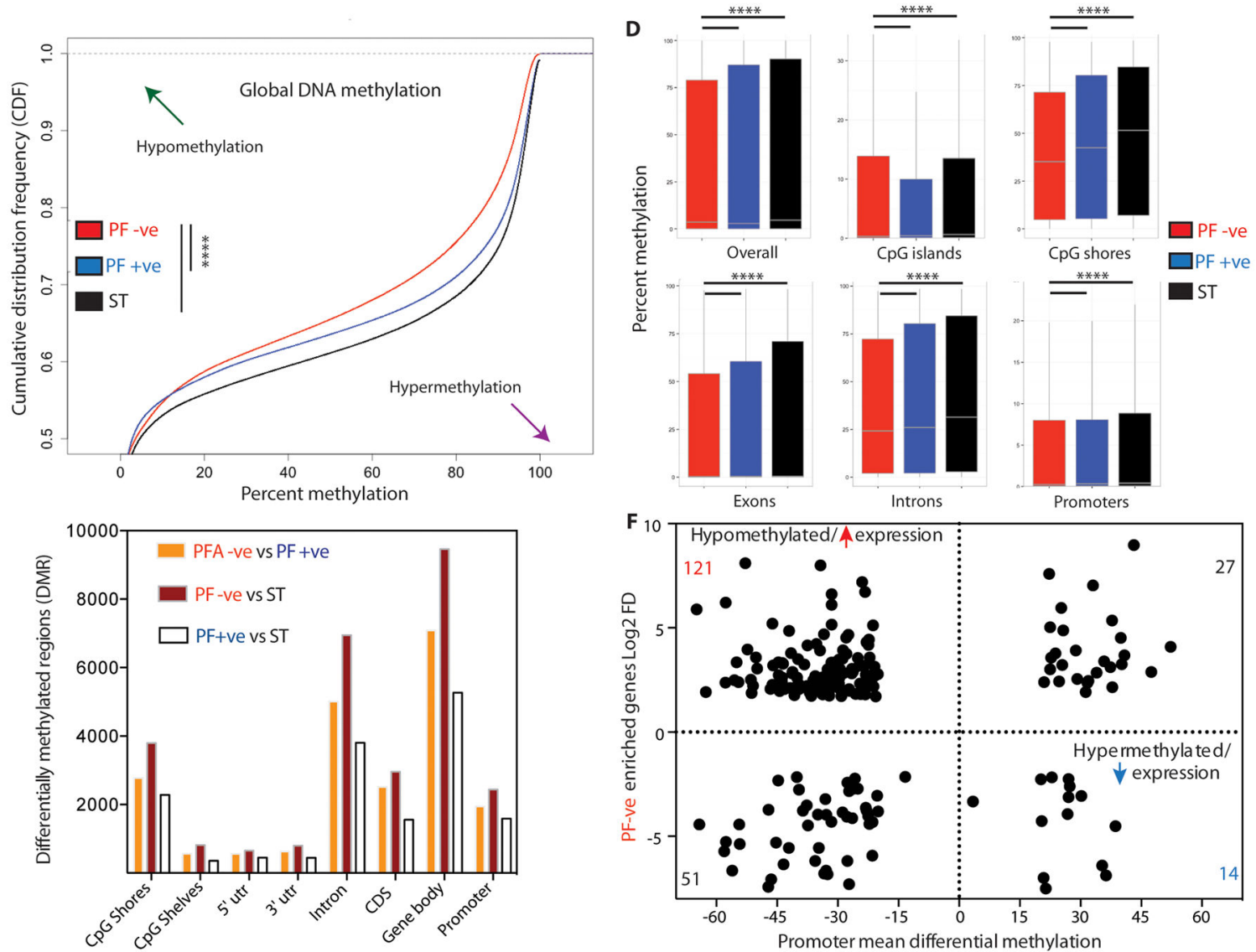

Figure 3. PF-ve ependymomas exhibit global DNA hypomethylation that drives gene expression A-B. Chromosomal methylation bar plot and ideogram indicating hypermethylated (pink) and hypomethylated (green) regions.

C. Cumulative distribution frequency (CDF) plots of global DNA methylation in PF-ve, PF +ve, and ST ependymomas (arrows indicate direction of hypo or hypermethylation). $* * * *$ Overall: $p=1.56 \mathrm{e}-93$ for $\mathrm{PF}-\mathrm{ve}$ vs $\mathrm{PF}+\mathrm{ve}$ and negligible (reported as 0.00 ) for PF-ve vs ST.

D. Percent methylation (overall, $\mathrm{CpG}$ islands, $\mathrm{CpG}$ shores, exons, introns, and promoters) in ependymomas. (p values provides in table $\mathrm{S} 7$ ).

Data are represented as means \pm SD. 
E. Differentially methylated regions (DMR) in $\mathrm{CpG}$ shores, $\mathrm{CpG}$ shelves, $5^{\prime}$ untranslated regions (UTR), 3' UTR, introns, coding DNA sequences (CDS), gene bodies, and promoters.

F. Integration of promoter DNA methylation (X-axis) and gene expression (Y-axis) for differentially expressed genes $(n=213)$ where DMR at promoters were identified. For all graphs, $\mathrm{PF}-\mathrm{ve}(\mathrm{n}=8), \mathrm{PF}+\mathrm{ve}(\mathrm{n}=4)$, and $\mathrm{ST}(\mathrm{n}=4)$. For $\mathrm{C}$ and $\mathrm{D}$, statistical significance was determined by Mann Whitney U/Wilcoxon test. Other $p$ values are provided in table $\mathrm{S} 7$. 

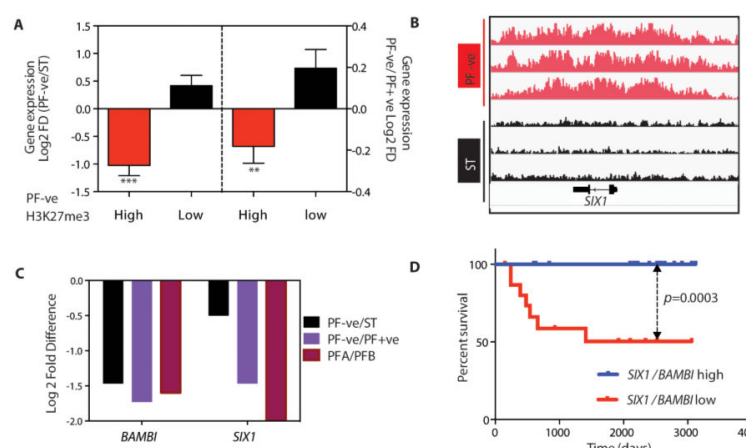

D

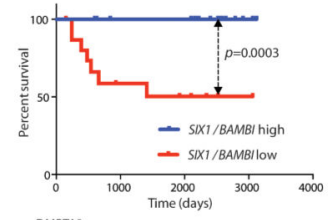

DMRTA2
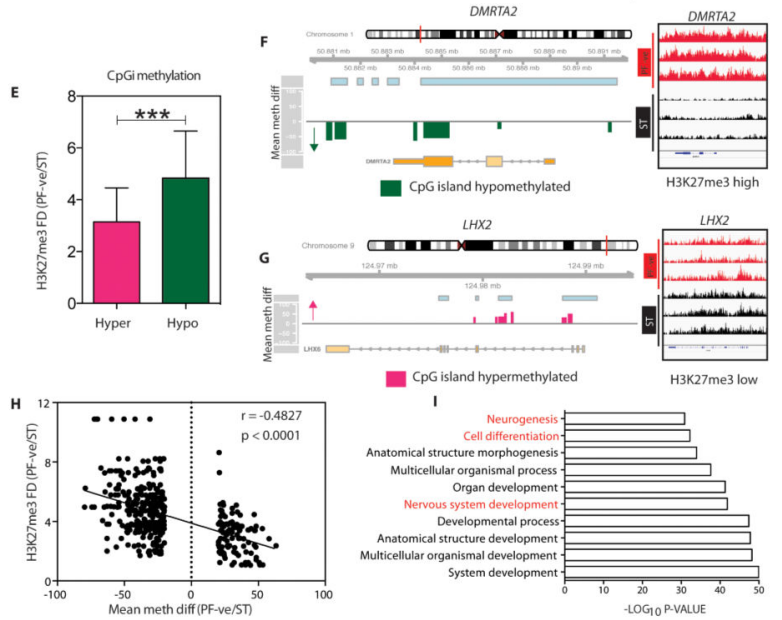

C C PG island hypermethylated

H3k27me3 low

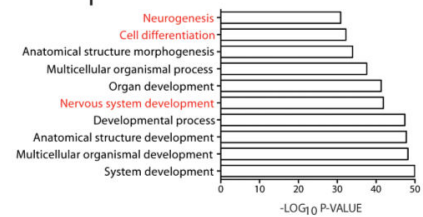

Figure 4. H3K27me3 distribution inversely correlates with CpGi methylation

A. Gene expression (Log2 FD, PF-ve/ST; $\mathrm{n}=5 / 3, * * * \mathrm{p}<0.0001$ and PF-ve/PF+ve; $\mathrm{n}=11 / 4$, ** $\mathrm{p}=0.0022$ ) in $\mathrm{H} 3 \mathrm{~K} 27 \mathrm{me} 3$ high versus $\mathrm{H} 3 \mathrm{~K} 27 \mathrm{me} 3$ low regions.

B. H3K27me3 distribution in the $S I X 1$ locus.

C. Comparison of $B A M B I$ and $S I X 1$ gene expression (Log2 FD) between PF-ve/ST $(\mathrm{n}=5 / 3), \mathrm{PF}-\mathrm{ve} / \mathrm{PF}+\mathrm{ve}(\mathrm{n}=11 / 4)$, and PFA/PFB $(\mathrm{n}=18 / 19$ (6)) ependymomas.

D. Kaplan-Meier survival curves in PF ependymomas (6) with low (red, $n=16$ ) or high (blue, $\mathrm{n}=21$ ) expression of $S I X 1 / B A M B I \mathrm{mRNA}$.

E. Fold difference (PF-ve/ST) of H3K27me3 enrichment for hyper- or hypo-methylated CpGi in PF-ve tumors. ***p<0.0001.

F. The DMRT2A locus on chromosome 1 with $\mathrm{CpGi}$ hypomethylation and enriched $\mathrm{H} 3 \mathrm{~K} 27 \mathrm{me} 3$.

G. The $L H X 2$ locus on chromosome 9 with $\mathrm{CpGi}$ hypermethylation and low H3K27me3.

H. Correlational analyses between H3K27me3 distribution (FD, PF-ve/ST, Y-axis) and DNA methylation (mean methylation difference, $\mathrm{X}$-axis).

I. Functional grouping of all genes that are epigenetically deregulated. Red indicates pathways related directly to neuronal development and cell differentiation (altered promoter DNA methylation and/or marked by promoter H3K27me3) and show altered gene expression.

Data in A and E are represented as means \pm SEM. Statistical significance was determined by two-sided, unpaired, two-tailed Student's t test; the log-rank test was used in D, and twotailed Pearson's Correlation in H. 

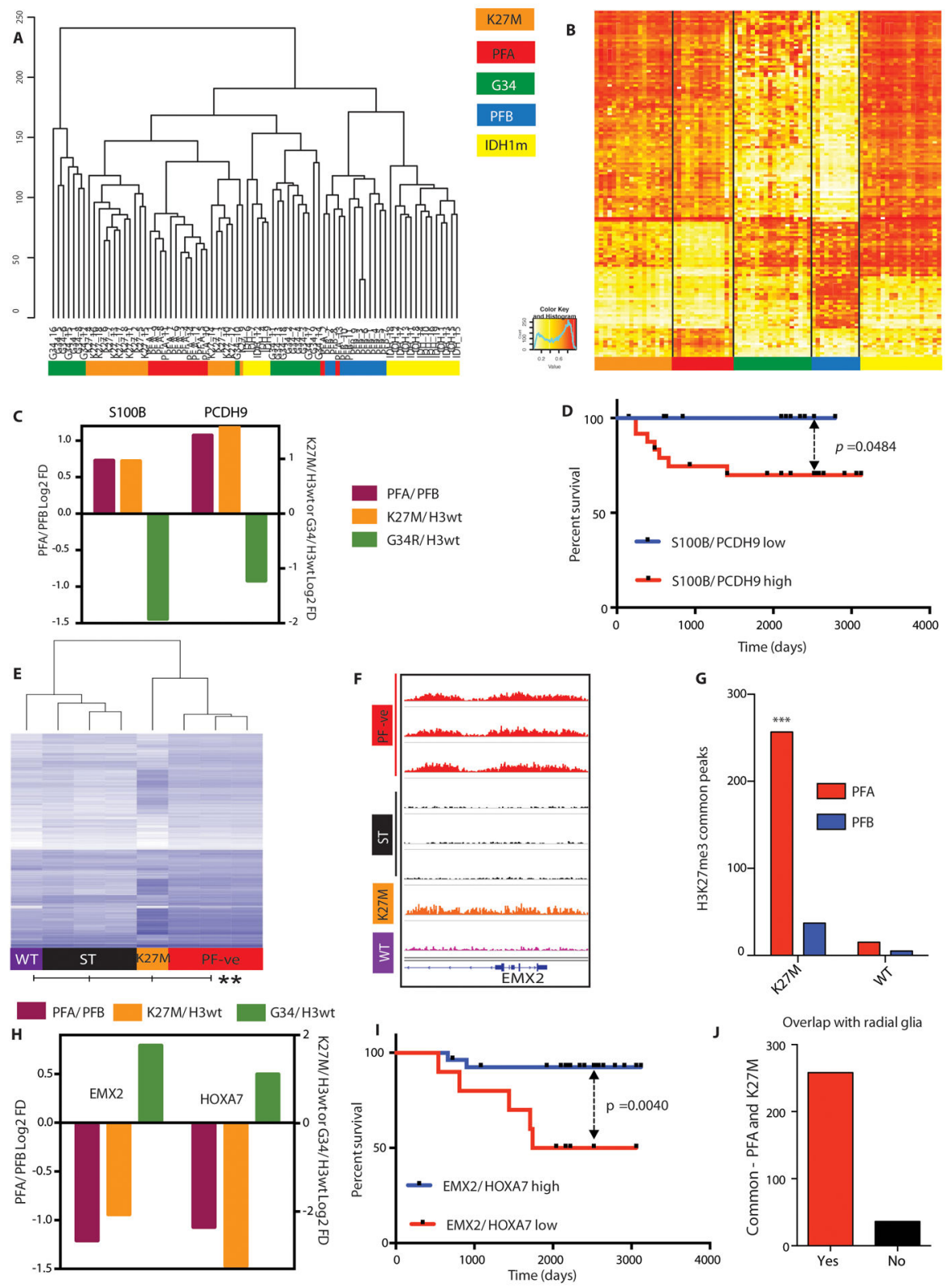

Figure 5. PFA/PF-ve ependymomas show similarities to H3K27M gliomas in DNA methylation and $\mathrm{H3K27} \mathrm{me} 3$ genome-wide distribution

A. Unsupervised clustering analyses of Illumina $450 \mathrm{~K}$ array DNA methylation data from PFA ( $n=14)$ and PFB (n=11) ependymomas (7) and H3K27M (n=18), G34 (n=18), and IDH1 mutant $(n=19)$ gliomas (20). All methylation sites were included in the analysis.

B. Heat map of representative hyper and hypomethylated $\mathrm{CpGi}$ from A.

C. Comparison of $S 100 B$ and $P C D H 9$ gene expression (Log2FD between PFA/PFB ( $\mathrm{n}=18 / 19$, left Y-axis, (6)), H3K27M/H3wt ( $\mathrm{n}=12 / 21$ (20), right Y-axis), and G34/H3wt $(\mathrm{n}=10 / 21$ (20), right Y-axis).

D. Kaplan-Meier curves in PF ependymomas with (6) high $(\mathrm{n}=25)$ or low expression $(\mathrm{n}=12)$ of $S 100 B / P C D H 9$ mRNA. 
E. Heat map displaying H3K27me3 peak intensities in PF-ve $(n=3)$, ST $(n=3)$, and neuronal progenitor cells (NPC) expressing H3.3K27M (K27M) or H3.3 wild type (WT) (22). Unguided hierarchical clustering was used for clustering samples based on $\mathrm{H} 3 \mathrm{~K} 27 \mathrm{me} 3$ enrichment. ** $p=0.0075$.

F. H3K27me3 distribution in the EMX2 locus in PF-ve and ST ependymomas and H3K27M-expressing and H3WT NPC.

G. Numbers of specific H3K27me3 peaks common to PFA (n=6) or PFB $(n=4)$ ependymomas (7) and H3K27M or WT NPC (22). ***p<0.0001.

H. Comparison of EMX2 and HOXA7 gene expression (Log2FD) between PFA/PFB (brown, left Y-axis, n=18/19, (6)), H3K27M/H3WT (orange (20), right Y-axis, n=12/21), and G34/H3wt (green, right Y-axis (20), n=10/21).

I. Kaplan-Meier survival curves in PF ependymomas (6) with high ( $\mathrm{n}=27)$ or low expression $(\mathrm{n}=10)$ of $E M X 2 / H O X A 7$ mRNA.

J. Overlap of differentially DNA or H3K27 methylated genes in PFA and H3K27M tumors with those in human radial glial gene expression data sets (23).

Statistical significance in D and I was determined by the log-rank test. In E and G, the significance of differences in peak numbers was evaluated by two-tailed Chi square test. 


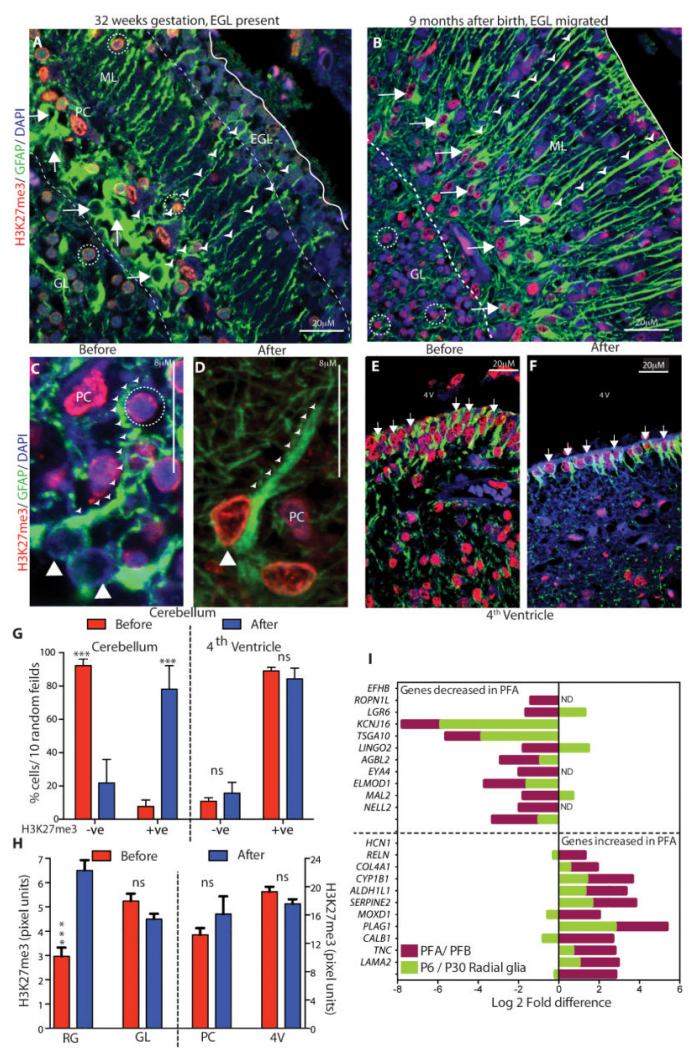

Figure 6. Radial glia in early cerebellar development show reduced H3K27me3

A-B. Representative confocal immunofluorescent images of human cerebellar tissues stained with antibodies against GFAP (green), H3K27me3 (red), and DAPI (blue) when the EGL is present before birth (A) or when EGL migration is complete (B). Arrows indicate H3K27me3 negative (A) or positive (B) nuclei in GFAP-positive radial glia. Arrowheads indicate radial glial processes. Dotted circles indicate granular cells. Solid lines indicate the pial surface, and the dotted lines indicate the extent of the EGL. Scale bars represent $20 \mu \mathrm{M}$. C-D. Higher power images of radial glia. Large arrowheads indicate H3K27me3 negative (C) or positive (D) nuclei in GFAP-positive radial glia. Small arrowheads indicate radial glial processes. Dotted circles indicate granular cells. Scale bars represent $8 \mu \mathrm{M}$.

E-F. Representative confocal immunofluorescent images from the human $4^{\text {th }}$ periventricular region. Scale bars represent $20 \mu \mathrm{M}$. Arrows indicate H3K27me3-positive nuclei in GFAPpositive radial glia.

G. The percentage of GFAP-positive/H3K27me3-negative or GFAP/H3K27me3-positive radial glia before and after development $(\mathrm{n}=3$, each). $* * * \mathrm{p}<0.0001$

H. Amount of H3K27me3 in each cell (H3K27me3 pixel units) quantified using NIH imageJ from various cell types in the PF before and after development. ***p<0.0001, for $\mathrm{n}$, see table S7.

I. Expression (Log2 FD) of factors that differentiate PFA from PFB ependymomas in PFA/PFB ( $n=18 / 19$ (6)) and radial glia from P6/P30 mice ( $\mathrm{n}=5$ each (29)). ND = not detected. 
Data in $\mathrm{G}$ and $\mathrm{H}$ are represented as means $\pm \mathrm{SEM}$; statistical significance was determined in G using two-tailed Chi square test and two-sided, unpaired, two-tailed Student's t test in H. $\mathrm{NS}=$ not significant. $\mathrm{RG}=$ radial glia, $\mathrm{EGL}=$ external granular layer, $\mathrm{ML}=$ molecular layer, $\mathrm{PC}=$ Purkinje cell, $\mathrm{IGL}=$ internal granular layer, $\mathrm{GL}=$ granular layer, $4 \mathrm{~V}=4$ th ventricle. 

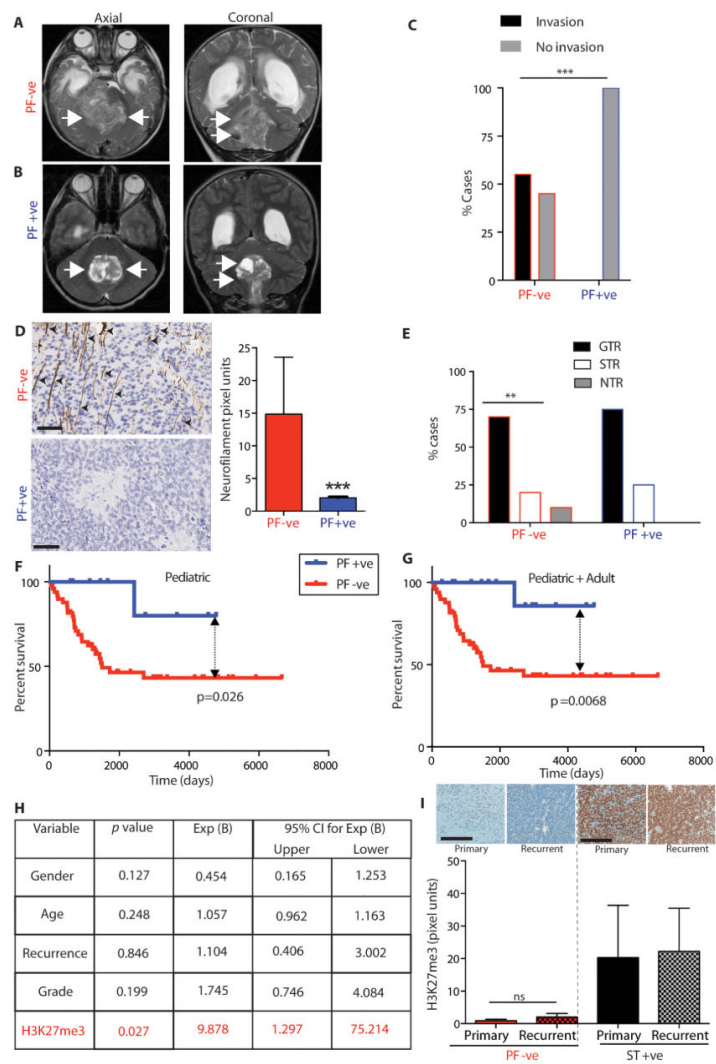

Figure 7. Decreased $\mathrm{H} 3 \mathrm{~K} 27 \mathrm{me} 3$ is a poor prognostic biomarker in pediatric $\mathrm{PF}$ ependymomas A-B. Representative axial and coronal T2 weighted MRI images from PF-ve (A) and PF+ve (B) ependymomas (white arrows).

C Percentage of cases with or without invasion in $\mathrm{PF}-\mathrm{ve}(\mathrm{n}=20)$ versus $\mathrm{PF}+\mathrm{ve}(\mathrm{n}=4)$. *** $p<$ 0.0001

D Tumor invasion and infiltration into surrounding brain tissue was compared between PF $+v e(n=4)$ and $P F-v e(n=28)$ by detecting neurofilaments in axons within tumor tissues (arrowheads) using immunohistochemistry (representative images from $\mathrm{PF}-\mathrm{ve}$ and $\mathrm{PF}+$ tumors and quantification). Scale bars represent $60 \mu \mathrm{M} . * * * \mathrm{p}=0.0017$.

E Extent of resection (GTR=gross total resection/no detectable tumor on post-surgical MRI, $\mathrm{STR}=$ subtotal resection/portion of tumor is detectable on post-surgical MRI, and NTR=near total resection/detection of minimal tumor on post-surgical MRI) in pediatric $\mathrm{PF}-\mathrm{ve}(\mathrm{n}=30)$ and $\mathrm{PF}+\mathrm{ve}(\mathrm{n}=4)$ ependymomas. $* * p=0.0047$.

F-G. Kaplan-Meier survival curves from pediatric $(F)$ or combined pediatric and adult $(G)$ cohorts of PF-ve ( $n=50$ in both F and G) and PF+ve (blue, $n=11$ in $F$ and $n=15$ in $G$ ).

H. Cox proportional regression analyses for overall survival in $\mathrm{PF}-\mathrm{ve}(\mathrm{n}=50)$ and $\mathrm{PF}+\mathrm{ve}$ $(n=11)$ ependymomas. $\operatorname{Exp}(B)$ is a measure of the hazard ratio.

I. H3K27me3 in matched primary and recurrent PF-ve and ST ependymomas $(n=3$ for each). Representative images and quantification are shown. Scale bars represent $200 \mu \mathrm{M}$. 
Data are represented as means \pm SEM in D and I. Statistical significance in C and E was determined by two-tailed Chi square test, in $\mathrm{D}$ and I by unpaired, two-sided, two-tailed $t$ test, and in $\mathrm{F}$ and $\mathrm{G}$ by the log-rank test. 
辛

\begin{tabular}{|c|c|c|c|c|c|c|c|c|c|c|c|c|c|c|c|c|c|c|c|c|c|}
\hline \multirow{3}{*}{ 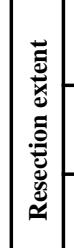 } & $\stackrel{z}{z}$ & $m$ & 0 & - & 0 & 0 & $\mathbb{z}$ & $\overleftarrow{z}$ & $\mathbb{z}$ & $\overleftarrow{z}$ & $\overleftrightarrow{z}$ & $\overleftrightarrow{z}$ & $\overleftrightarrow{z}$ & $\mathbb{z}$ & $\overleftrightarrow{z}$ & $\vec{z}$ & $\mathbb{z}$ & $\mathbb{z}$ & $\mathbb{z}$ & $\varangle$ & $\overleftrightarrow{z}$ \\
\hline & 点 & 0 & - & in & $m$ & $N$ & $\mathbb{z}$ & $\overleftrightarrow{z}$ & $\overleftrightarrow{z}$ & $\overleftrightarrow{z}$ & $\overleftrightarrow{z}$ & $\overleftrightarrow{z}$ & $\overleftrightarrow{z}$ & $\overleftrightarrow{z}$ & $\overleftrightarrow{z}$ & $\mathbb{z}$ & $\mathbb{z}$ & $\mathbb{z}$ & $\mathbb{z}$ & $\mathbb{z}$ & $\overleftrightarrow{z}$ \\
\hline & 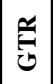 & $\bar{\lambda}$ & $m$ & $a$ & - & r & $\mathbb{z}$ & 艺 & $\mathbb{z}$ & $\overleftrightarrow{z}$ & $\overleftrightarrow{z}$ & $\overleftrightarrow{z}$ & $\overleftrightarrow{z}$ & $\mathbb{z}$ & $\overleftrightarrow{z}$ & $\overleftrightarrow{z}$ & $\mathbb{z}$ & $\overleftrightarrow{z}$ & $\overleftrightarrow{z}$ & $\overleftrightarrow{z}$ & $\mathbb{Z}$ \\
\hline & 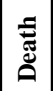 & $=$ & 0 & † & - & † & $\infty$ & - & $\sim$ & 0 & 0 & $\mathscr{A}$ & - & 0 & - & t & 0 & - & 0 & 0 & 0 \\
\hline
\end{tabular}

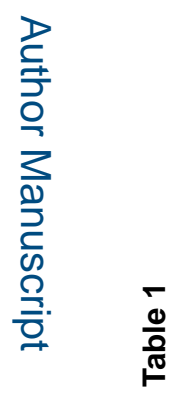

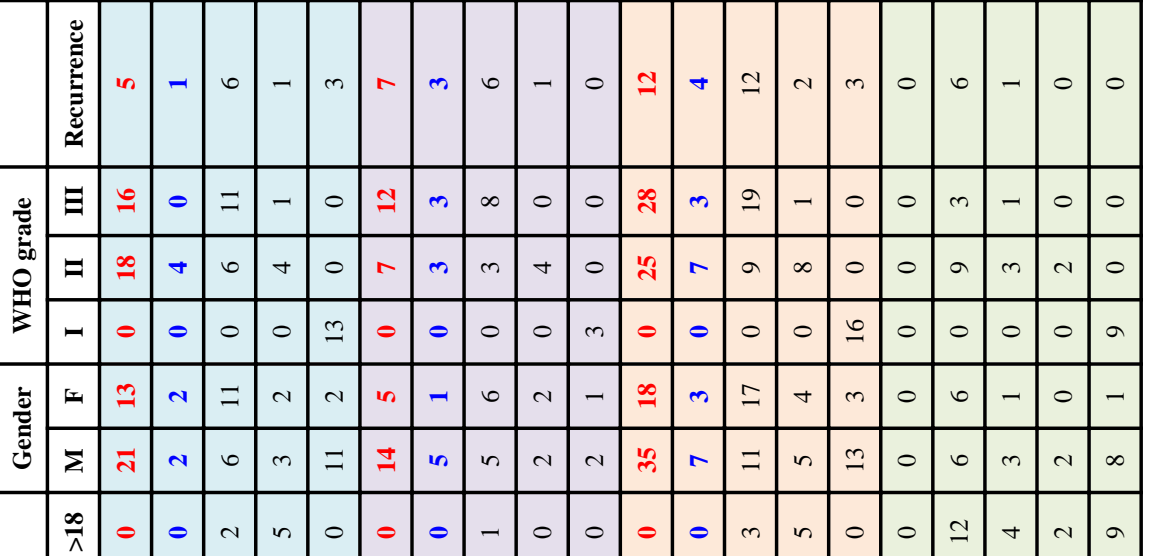

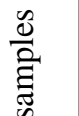

로을

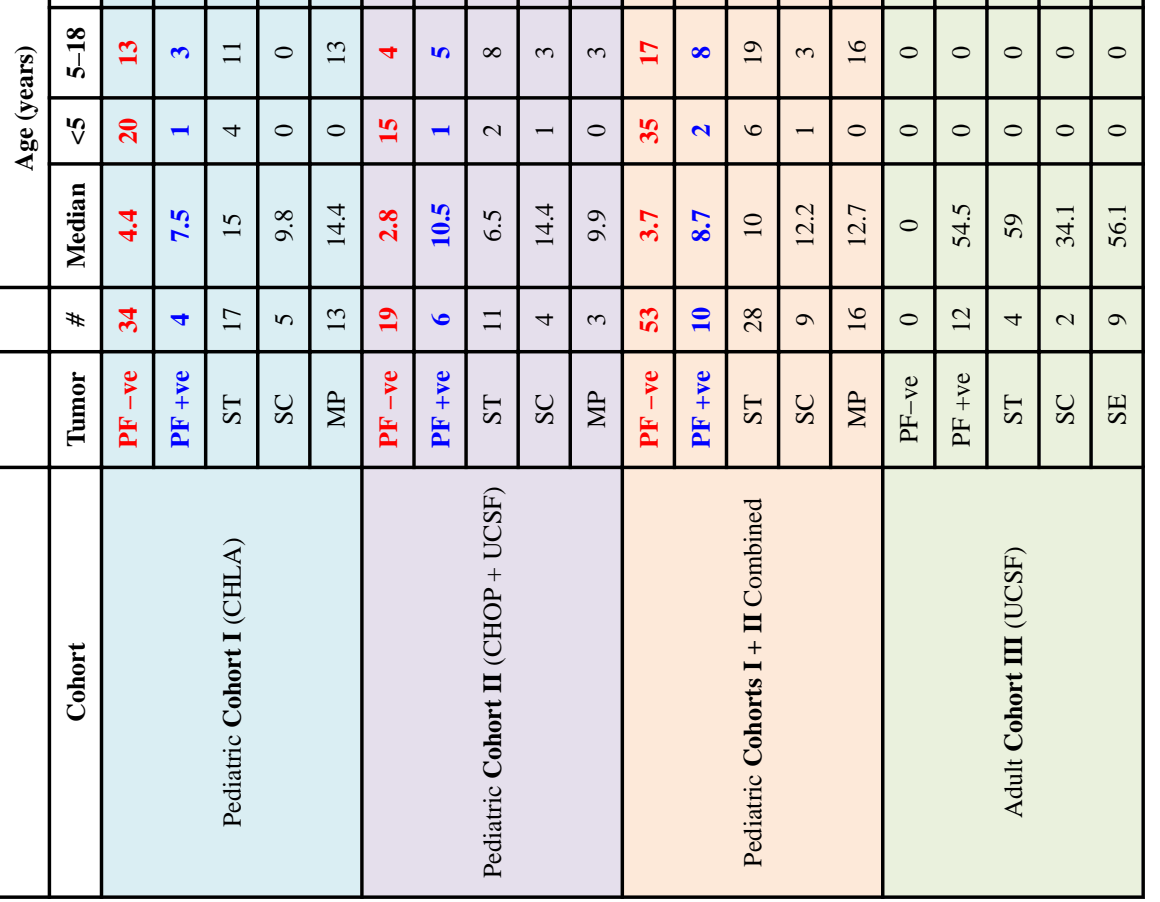

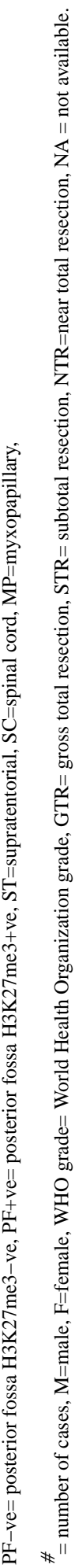

Sci Transl Med. Author manuscript; available in PMC 2017 May 23. 